\title{
The Importance of Information and Communication Technology in English Learning: Indigenous Students' Perspectives
}

\author{
Johan@Eddy Luaran ${ }^{1 *}$, Fazyudi Ahmad Nadzri², Kamarol Baharen \\ Mohd Rom ${ }^{3}$ and Jasmine Jain ${ }^{4 *}$ \\ ${ }^{1,2,3}$ Faculty of Education, Universiti Teknologi MARA,Shah Alam, Selangor, Malaysia \\ ${ }^{4}$ School of Education, Taylor's University, Subang Jaya, Malaysia \\ *johaneddy@salam.uitm.edu.my
}

Published online: 27 December 2016

To cite this article: Luaran J. @ E., Fazyudi Ahmad Nadzri, Kamarol Baharen Mohd Rom and Jasmine Jain. 2016. The importance of Information and Communication Technology in English learning: Indigenous students' perspectives. Malaysian Journal of Distance Education 18(1): 87-101. http://dx.doi.org/10.21315/mjde2016.18.1.6

To link to this article: $\mathrm{http} / / / \mathrm{dx}$.doi.org/10.21315/mjde2016.18.1.6

\begin{abstract}
The increasing dependence of people on technology nowadays is evident through the transformation of various sectors, placing Information and Communication Technology (ICT) as an enabler in enhancing human capabilities and participations as a member of society. Policymakers and educators agreed that ICT is a supreme factor in leveraging positive effects on the students' achievements at large. Although myriad of studies have focused on ICT integration in education of students from the rural communities, the ICT issues among indigenous students have been sidelined. This study intended to address this gap by focusing on the views of indigenous students on the importance of ICT in learning English. A total of 94 indigenous students from three districts in Pahang, Malaysia were involved in this study. A quantitative approach was employed where questionnaires were used as instruments to gauge the participants' views. The findings revealed that the indigenous students have low ICT competence but have positive attitude in the use of ICT in teaching and learning. The level of ICT use in classroom was found to be low and, surprisingly, most of them preferred to have Internet-related activities in learning English.
\end{abstract}

Keywords: Information and Communication Technology (ICT), teaching and learning, indigenous students, learning English 


\section{Introduction}

The advancement of technology has profoundly altered lives of people as the world progresses into technologically more sophisticated age. The expanding network known widely as the Internet, has tremendously improved communication and enabled retrieval of information with ease. Acquisition of knowledge and means of communication seem to be effortless with more advanced technology available. This has led to creation of the term Information and Communication Technology (ICT) to describe the closely intertwined relationship of technology, communication and technology. A good example of this is the smart phones and tablet computers, to cater to the increasing dependence of people on ICT.

The proliferation of ICT in the digital age has also transformed the educational field in myriad of ways; among others are the setting, the teaching and learning process and the teaching aids used in classrooms. ICT also provides vast opportunities for learners to expand themselves. According to UNESCO (2004), ICT enables the access to vast stores of knowledge beyond the school that includes the multimedia tools (Anderson, 2005). When everything is ICT related, it is irrelevant to continue educating students in the traditional environment. As stated by Bingimlas (2009), traditional educational environment is insufficient to make learners to be productive in today's workplace. The current society requires competent workers who are technologically literate and able to utilise technology for optimum productivity. ICT is also recognised as an enabler for more effective learning as it gives fast and accurate feedback to students by speeding up computations and graphing. Hence, students have more opportunity to focus on strategies and interpretation. In addition to that, a study by Look (2005) revealed from a review of 219 studies on the use of technology in education found that the students who experienced technologically rich environment recorded positive effects on their achievements in all subject areas.

As ICT integration could provide students with more benefits, it is seen as vital for schools and institutions to provide the best ICT integrated education to their students. It is not a surprise anymore when ICT could actually improve students' performance and boost their achievements. 


\section{Indigenious People}

Indigenous people are also known as the aborigines. They are approximately 370 million of this population worldwide, living in 90 countries and with a majority of them (70\%) residing in Asia (Cultural Survival, 2012). Indigenous populations are communities that live within, or are attached to, geographically distinct traditional habitats or ancestral territories, and who identify themselves as being part of a distinct cultural group, descended from groups present in the area before modern states were created and current borders defined. They generally maintain cultural and social identities, separate from the mainstream or the dominant society and culture (World Health Organization, 2012).

In Malaysia, the indigenous people are referred as Orang Asli-a term given to the aboriginal people of Peninsular Malaysia. According to the Aboriginal Peoples Act 1954 (2006), an aborigine is:

1. any person whose male parent is or was, a member of an aboriginal ethnic group, who speaks an aboriginal language and habitually follows an aboriginal way of life and aboriginal customs and beliefs, and includes a descendant through males of such persons;

2. any person of any race adopted when an infant by an aborigine who has been brought up as an aborigine, habituallyspeaks an aboriginal language, habitually follows an aboriginal way of life and aboriginal customs and beliefs and is a member of an aboriginal community; or

3. the child of any union between an aboriginal female and a male of another race, provided that the child habitually speaks an aboriginal language, habitually follows an aboriginal way of life and aboriginal customs and beliefs and remains a member of an aboriginal community.

According to the Department of Statistics Malaysia (2010), 76.9\% of the Indigenous population still live below the poverty line while $35.2 \%$ is said to live in hard-core poverty compared to $1.4 \%$ nationally. During the English colonisation era, through the Aboriginal People Ordinance 1954, indigenous people were excluded from development with the excuse of forbidding exploitation and retaining their traditional lifestyle. This, however, led to the under development of indigenous people population. They were forced to live in a traditional way and stay away from development. However, the 
independence of Malaysia in 1957 resulted in providing more attention and consideration on the needs and rights of indigenous people population. A department was set up to cater to any issues pertaining to the aborigines in Malaysia, with the responsibility of managing the development and welfare of Indigenous people. The department is known as Jabatan Kemajuan Orang Asli (JKOA).

According to Jabatan Kemajuan Orang Asli (2011), the indigenous people population has increased from 141,230 in 2006 to 178,197 in 2010. However, they are still the minority who made up only $0.7 \%$ of the country's population. There are three main groups of indigenous people known as Senoi, Negritos and Traditional Malay/ Proto-Malay. Of these three groups, Negrito made up the smallest population followed by Traditional Malay/ Proto Malay. According to the information from JAKOA, Senoi group favours uphill areas and builds big huts occupied by several families. The majority of the Traditional Malay/ Proto- Malay groups live in the Southern part of Peninsular Malaysia while the Negrito population lives in the remote area and practices the nomad life style.

Table 1 Indigenous population according to states

\begin{tabular}{lcccc}
\hline State & Negrito & Senoi & $\begin{array}{c}\text { Traditional Malay / } \\
\text { Proto Malay }\end{array}$ & Total \\
\hline Pahang & 925 & 29,439 & 37,142 & 67,506 \\
Perak & 2413 & 50,281 & 605 & 53,299 \\
Kedah & 251 & 19 & 0 & 270 \\
Selangor & 3 & 5073 & 12,511 & 17,587 \\
Kelantan & 1381 & 12,047 & 29 & 13,457 \\
Terengganu & 34 & 818 & 41 & 893 \\
Negeri Sembilan & 0 & 96 & 10,435 & 10,531 \\
Melaka & 1 & 28 & 1486 & 1515 \\
Johor & 1 & 55 & 13,083 & 13,139 \\
\hline Total & 5009 & 97,856 & 75,332 & 178,197 \\
\hline
\end{tabular}

The majority of indigenous people community live in the rural areas. Poverty has always been associated with this community, leading to limited access to facilities and development which includes opportunities to education. 


\section{ICT and aborigines elsewhere}

Literature has reported few models that were carried out and was found to reinforce the knowledge by the indigenous people. In a study involving 19 schools serving indigenous pupils of United States, it was found that the use of ICT in the ' 4 Directions Project' fostered networking among the pupils with the immediate people from their social circle, a strong schoolcommunity and school-home focus as well as encouraging aborigines' lifelong learning through the technological support provided (Resta, 2011). A similar effort of integrating ICT can also be seen in Thailand in a project called 'Thailand Indigenous Knowledge Initiative' where a policy of making indigenous children have more culturally responsive learning opportunities was introduced (Kaewdang, 2000). It was believed that by doing so, the indigenous peoples in their countries can fully participate in knowledge societies. From the scarce literature, it infers that the indigenious people worldwide has rather high acceptance to using ICT and are gradually moving towards favourable adoption of ICT to improve the well-being of their people and their knowledge. However, there is a need for a study to further look into this in the local context.

\section{Problem Statement}

The emerging trend of ICT in education has leveraged the education in Malaysia. As ICT is important and crucial in the development of knowledgebased society, its integration has been placed as one of the objectives of Malaysian education. However, digital divide has inhabited the initiatives of Ministry of Education (MOE) to expand the digital literacy to all. Anderson (2005) has highlighted the definition of 'digital divide' as a gap between those who have ample access to ICT and those who lack such accessibility. Although it is understood that ICT improves teaching and learning process, it is vital to look at the use of ICT among indigenous students. The majority of indigenous people live in rural areas with limited access to ICT. The digital gap may be wider as many of them could not benefit from the integration of ICT in education. While other students could experience the use of ICT in their teaching and learning process, indigenous students might not have the equal chance to experience it. 
The current study intends to explore this problem, focusing on the learning of the English language. Specifically, this study investigates the level of ICT competency of indigenous students, the differences of ICT competency that may exist between male and female indigenous students, the level of ICT usage in English classroom, as well as the perceived importance of ICT in English learning among the indigenous students.

\section{Research Questions}

The research questions are:

1. What is the level of ICT competency among the indigenous students?

2. What are the attitudes of indigenous students towards ICT?

3. What is the level of ICT integration in English classroom?

4. How do indigenous students perceive the importance of ICT in learning English?

\section{Research Design}

A quantitative approach was employed in this study. Questionnaires were used in order to obtain information on the ICT competency, gender differences in ICT competency, attitudes towards ICT, level of ICT integration in English classroom and their views on the importance of ICT in education. The participants for this study were the indigenous students in secondary schools in Pahang. A total of 94 indigenous students ranging from form two until form five from three districts in Pahang were selected to participate in this study. Table 2 shows the distribution of the respondents according to their gender and age.

Table 2 Distribution of respondents by gender and age

\begin{tabular}{lcc}
\hline Demographic variables & Frequency & Percentage (\%) \\
\hline Gender & & \\
$\quad$ Male & 30 & 33 \\
$\quad$ Female & 63 & 67 \\
Age & & \\
$12-14$ & 24 & 26.6 \\
$15-17$ & 69 & 73.4 \\
\hline Total & 93 & 100.0 \\
\hline
\end{tabular}




\section{Results and Discussion}

\section{Level of ICT Competency of Indigenous Students}

It was found that most of the respondents have computer access at home, as shown in Table 3. While for the Internet access, as shown in Table 4, more than $90 \%$ of the respondents do not have internet access at home. Access to computer and the internet is seen as an enabler that will help to increase the competence level in ICT among the students. With the adequate infrastructure such as computer and the internet, the students could have the experience of utilising them and, indirectly, this helps to improve their ICT competence. This is supported by Luu and Freeman (2011) who claim that students with ICT access at home will have more ICT experience. This is similar to the finding of a study by Siti Zubaidah and Azmanirah (2009) on rural community college students. Their finding reveals similarity with the present study where internet accessibility and computer experience are related to the students' computer competence.

Table 3 Statistic of respondents' computer access at home

\begin{tabular}{ccc}
\hline Access to computer & Frequency $(n)$ & Percentage (\%) \\
\hline Yes & 56 & $59.6 \%$ \\
No & 37 & $39.4 \%$ \\
Total & 93 & $100 \%$ \\
\hline
\end{tabular}

Table 4 Statistic of Internet access at home

\begin{tabular}{ccc}
\hline Access to Internet & Frequency $(n)$ & Percentage (\%) \\
\hline Yes & 3 & $3.2 \%$ \\
No & 90 & $96.8 \%$ \\
Total & 93 & $100 \%$ \\
\hline
\end{tabular}

It can also be found that most of the respondents are in the low category of ICT competency. Among the four skills listed, the indigenous students seem to be most competent in general computing skills. The lowest mean value goes to email application skill. It indicates that the indigenous students perceive email application skill as the hardest compared to the other skills. 
The highest mean value is for playing computer game. This shows that the indigenous students rated themselves highly in playing computer games. This is not surprising as playing computer games is interesting and may attract the students' attention. They are more likely to be motivated in using computer for games. It is also visible from the findings that installing software is perceived as the hardest skill to perform by the indigenous students. Installing software requires users to understand the instructions and procedures. This might be hard for the indigenous students as they have limited English proficiency and all the instructions and procedures provided are in English. To further elaborate on the email application skill, it was also found that the indigenous students are more competent in creating emails than adding attachments to emails. The students are taught how to create and send emails at schools, thus, they were confident in rating themselves as competent in creating emails. The ability to add attachments to emails may be harder for them as the process is quite complicated when especially users have limited computer knowledge and limited English proficiency. This is supported by Teck and Lai (2011) who stated that English proficiency affects ICT competence. This proves that in order to have better skills in ICT, one must have sufficient knowledge in the English language. This is due to the fact that English is the language used in most ICT tools.

\section{Indigenous Students' Attitudes towards ICT}

It can also be found that the indigenous students have positive attitudes toward ICT. This finding contradicts Musa et al. (2011) report, which claimed that negative attitudes in ICT are always the norm among people in rural areas. As most of the indigenous communities reside in rural areas, they are expected to have negative attitudes towards ICT. However, this study found that the indigenous students are positive towards ICT. The finding of the present study, however, is similar with the one reported by Tengku Faekah (2005). Tengku Faekah (2005) found that the students in rural areas have positive attitudes toward ICT but have low level of ICT skills. In the present study, the indigenous students have positive attitudes toward ICT despite their low ICT competency.

The findings are further elaborated on ICT attitudes according to the computer and internet accessibility. It can also be found that more positive attitudes were exhibited by the students who have access to computer with 
internet. Accessibility to computer with the internet means that the students are exposed more likely to the way to using them. Thus, it helps to cultivate positive attitude towards it. The same notion was echoed by Mojgan et al. (2009), mentioning 'positive attitudes are developed when users are sufficiently comfortable with technology and are knowledgeable on its use'.

\section{ICT Integration in English Classroom}

The third research question of this study focuses on the level of ICT usage in English classrooms. Four ICT-related activities were highlighted in the questionnaire and the respondents were asked to rate the frequency of use for each activity in their English classroom. Based on Table 5, it can be found that most of the respondents had never experienced all the ICT-related activities highlighted in their English classroom.

Table 5 Integration of ICT in classroom

\begin{tabular}{lcc}
\hline Theme & Frequency $(n)$ & Percentage $(\%)$ \\
\hline Limited use of ICT in classroom & 9 & 9.6 \\
No ICT integration at all & 46 & 48.9 \\
ICT is so confusing & 5 & 5.3 \\
ICT is fun & 8 & 8.5 \\
Given access to computer during the lesson & 21 & 22.3 \\
Teacher help to use ICT & 7 & 7.4 \\
\hline
\end{tabular}

The findings indicate that teachers did not fully integrate ICT in the teaching and learning of English. Teaching may still be conducted according to the traditional method. Teachers might face barriers in integrating ICT in their English lessons. The barriers can be classified into two levels - teacherlevel barrier and school-level barrier. As for the teacher-level barrier, the barriers include lack of time, lack of confidence and resistance to changes. School-level barrier, on the other hand, encompasses the lack of effective training and shortage of resources. A study by Goktas, Yildirim and Yildirim (2009) found that crowded classrooms, inadequate ICT-related courses, lack of computers, and lack of teachers' motivation to be among the factors that had impeded the ICT integration in class. The finding of that study might be relevant to this study. Teachers might not fully integrate ICT as they have 
limited ICT infrastructure and the condition of the classroom might not permit the utilisation of ICT. From the observation of the researcher when conducting the research, most of the classrooms in the schools involved were not large enough to cater to the big number of students. This situation might hinder the utilisation of ICT as the teachers need to focus more on classroom management. When the teachers teaching in the classrooms that are not equipped with computers need to apply ICT, they always ask the students to go to the computer laboratory.

Limited use of ICT in the classroom means limited experience and exposure to ICT for the students. When students are not exposed to ICT and the benefits of using it, they will not see the benefits and goodness of the technology. Noiwan, Piyawat and Norcio (2005) reported that students who are confident in using computers and understand the benefits of the computer have better attitudes and tend to use computers more if compared with their counterparts who do not share the same perception. This indicates that the level of ICT usage in classrooms will affect students' perceived usefulness of ICT.

\section{Perceived Importance of ICT in Learning English}

In finding the views of the indigenous students on the importance of ICT in learning English, five open-ended questions were formulated. Responses from these questions were used to determine the indigenous students' perceived importance of ICT in learning English and were then triangulated with the findings from the previous research questions.

Most of the indigenous students agreed that ICT helps them in learning English. This indicates that the indigenous students are aware of the advantages of ICT in education. This is due to the exposure to ICT they received in school. They know the importance of the internet today, thus, it is not surprising if they hold positive perceptions on ICT's role in enhancing their English learning. This was found when the researcher asked the students if they knew what the internet was. Almost all stated that they knew what the internet was and they knew what Facebook was.

In order to further explore the students' views on the importance of ICT, they were asked how ICT could help them. The responses from this 
question reflected the indigenous students' knowledge of ICT. To answer this question, they need to know what ICT is and what ICT can do. Based on the results, most of the students agreed that ICT could help them to seek information. The internet is abundant with overwhelming information. Thus, the use of it in class helps the students in their learning process. Siti Zubaidah and Azmanirah (2009) echoed that ICT offers a lot of resources and information. The internet provides students with fun activities as 'websites are full of animations, colours, sounds, pictures, interactive forms and digital video clips; promoting students' motivation and helping them enjoy the learning process' (Gitsaki and Taylor, 1999).

Table 6 How ICT help in learning English

\begin{tabular}{lcc}
\hline Theme & Frequency $(n)$ & Percentage (\%) \\
\hline Easy to understand & 23 & 24.5 \\
Seek Information & 64 & 68.1 \\
Guidance & 7 & 7.4 \\
\hline
\end{tabular}

Most of the students are not satisfied with the level of ICT integration in their English classroom. This happens as there is no ICT element at all in their English classroom. This feeling of dissatisfaction from the students implies that they yearn for ICT usage in their teaching and learning process. The use of traditional method in teaching may not be suitable anymore. However, most of the students have positive views on their current English learning. They felt that their English learning process is interesting, satisfying and very good. When the researcher asked to provide reasons for their responses, it is however quite surprising that most of the students chose to give no opinions on this matter. From observation, the students might not feel secure to state their reasons. This might be attributed to the presence of a teacher who helped the researcher in conducting the survey. However, from the reasons stated by the students, $24.5 \%$ agreed that they had funny and helpful teachers. This reason contributes to the positive views on their English language learning.

Almost all of the indigenous students hold the belief that ICT means computer and the internet. Thus, when asked on their preferred ICT-related activities to be conducted in their English class, the majority mentioned the use of the internet. This is related to the second question asked to the 
respondents previously. As mentioned by the indigenous students, they felt that ICT could help them seek information. This is also depicted in the second highest preference for ICT-related activities where the students want to be given access to computer to find information. When students are given access to the internet, they can enhance their higher order thinking skill (Singhal, 1997). This can be achieved when students search information on the internet and evaluate the usefulness or the authenticity of the information on their own.

The responses from the open-ended questions reveal that the indigenous students do perceive ICT as important in learning English. This finding supports the findings on ICT competence and ICT attitudes of the indigenous students. As indicated in the previous sections, Orang Asli students have low ICT competence. As they are not exposed to the use of ICT in school, they have limited ICT competence. Most of the indigenous students come from rural areas. They have limited access to basic infrastructure such as electricity. They also do not have the internet coverage at their residential area. Even when they are given the 1Malaysia netbook, they cannot fully utilise it due to the limited access to electricity and the internet. The indigenous students are provided hostel facility but most of them stay in hostel during weekdays. Hence, they are not allowed to use electrical appliance in their hostel. Thus, the situations limit them from fully utilising the netbook.

The indigenous students possess positive attitudes toward ICT. This supports their view on the importance of ICT in learning English. Their positive attitudes affect how they view ICT. According to Mojgan et al. (2009), an important factor in computer implementation is the users' acceptance and the acceptance is influenced by their attitudes. When the students have positive attitude towards ICT, they will accept its diffusion and able to see the benefits that stems from it. Thus, it is acceptable to say that the indigenous students surveyed have defied the odds by not only having positive views about ICT but also by being ready to embrace modernisation that ICT brings. In the context of education, the indigenous students are also receptive to the digital transformation in teaching and learning. 


\section{Conclusion}

This study has successfully shed light on competency of ICT, ICT attitude and the perceived importance of ICT in English learning among the indigenous students. The findings revealed that the indigenous students posses low ICT competency despite their positive attitudes to it. The present study provides a platform for a better understanding of the inadequate skills of the indigenous students who are often marginalised. The Ministry of Education, various stakeholders and educators should place more priority to ensure better use of ICT among the indigenous students and to ensure that they receive equal opportunities for quality education. Although the indigenous people are minority in Malaysia, their rights to equal education must not be denied. It is important to note from this study that the indigenous students already have the right attitude towards ICT, inferring that ample supports and efforts in improving their ICT competence could bring major success in learning. It is also important to note that the indigenous students have limited internet access leading to the lack of knowledge in ICT among them. This is further exacerbated by low ICT integration in their English lessons. As ICT has been proven to help ESL learners, initiatives in enhancing the utilisation of ICT in English classes should be further strengthened.

\section{References}

Aboriginal Peoples Act 1954. 2006. Laws of Malaysia, Act 134. Malaysia: The Commissioner of Law Revision. Malaysia under the Authority of the Revision of Laws Act, 1968 in collaboration with Percetakan Nasional Berhad.

Anderson, J. 2010. ICT transforming education. A regional guide. Bangkok: UNESCO Bangkok. http://unesdoc.unesco.org/images/0018/001892/189216e.pdf (accessed 30 September 2012).

2005. IT, e-learning and teacher development. International Education Journal ERC 2004, Special Issue 5(5): 1-14. http://ehlt.flinders.edu.au/education/iej/ articles/v5n5/v5n5.pdf\#page=5 (accessed 30 September 2012).

Bingimlas, K. A. 2009. Barriers to the successful integration of ICT in teaching and learning environments: A review of the literature. Eurasia Journal of Mathematics, Science \& Technology Education 5(3): 235-245. http://www.dr-alghimlas.com/Files/ Research/EURASIA_v5n3_Bingimlas3FS6AIRZ.pdf (accessed 8 December 2011).

Cultural Survival. 2012. Who are indigenous people. http://www.culturalsurvival.org/ node/10275 (accessed 30 October 2012). 
Department of Statistics Malaysia. 2010. Population and housing census of Malaysia 2010: Preliminary count report. Putrajaya, Department of Statistics Malaysia.

Gitsaki, C. and R. P. Taylor. 1999. Internet-based activities for the ESL classroom. ReCALL 11(1): 47-57. http://www.eurocall-languages.org/recall/pdf/rvol11 nol. pdf\#page=47 (accessed 15 October 2012).

Goktas, Y., S. Yildirim and Z. Yildirim. 2009. Main barriers and possible enablers of ICTs integration into pre-service teacher education programs. Educational Technology \& Society 12(1): 193-204. http://www.ifets.info/journals/12_1/15.pdf (accessed 19 November 2012).

Jabatan Kemajuan Orang Asli. 2011. Official website of Ministry of Rural and Regional Development. http://www.rurallink.gov.my/c/document_library/ get_file?uuid=993f90d2-2366-4e73-81b0-a67e7e22e991\&groupId=977333 (accessed 17 November 2012).

Kaewdang, R. 2000. Indigenous knowledge for a learning society [online paper]. Paper presented at the 6th UNESCO-APEID International Conference on Education, Bangkok, Thailand, 12-15 December 2000. http://www.unescobkk.org/education/ accid/conference/Pancl_1/Rung.doe (accessed 10 July 2002).

Luu, K. and J. G. Freeman. 2011. An analysis of the relationship between information and communication technology (ICT) and scientific literacy in Canada and Australia. Computers \& Education 56(4): 1072-1082. http://www.sciencedirect.com/ science/article/pii/S0360131510003295\# (accessed 20 November 2012). https:// doi.org/10.1016/j.compedu.2010.11.008.

Look, D. 2005. Discussion paper: Impact of technology on education. Paper prepared for PUSD Excellence Committee. http://pleasanton.k12.ca.us/Superintendent/ Downloads/Technology.pdf (accessed 11 December 2011).

Mojgan Afshari, Kamariah Abu Bakar, S. L Wong, Bahaman Abu Samah and S. F. Foo. 2009. Factors affecting teachers' use of information and communication technology. International Journal of Instruction 2(1): 77-104. http://www.e-iji. net/dosyalar/iji_2009_1_5.pdf (accessed 1 October 2012).

Musa Abu Hassan, Bahaman Abu Samah, Hayrol Azril Mohamed Shaffril and J. L. D'silva. 2011. Perceived usefulness of ICT usage among JKKK members in Peninsular Malaysia. Asian Social Science 7(10): 255-266. DOI: http://dx.doi.org/10.5539/ ass.v7n10p255 (accessed 26 October 2012).

Noiwan, J., T. Piyawat and A. F. Norcio. 2005. Computer attitude and computer self-efficacy: A case study of Thai undergraduate students. 11th International Conference on Human-Computer Interaction, Nevada, USA. http://userpages.umbc.edu/ norcio/ papers/2005/Noiwan\%20Cmp-HCII2005.doc.pdf (accessed 15 November 2012).

Resta, P. 2011. ICT and indigenious people. Russia: UNESCO Institute for Information Technologies in Education.

Singhal, M. 1997. The internet and foreign language education: Benefits and challenges. The Internet TESL Journal 3(6). http://iteslj.org/Articles/Singhal-Internet (accessed 5 November 2012).

Siti Zubaidah Ahmad Zuhari and Azmanirah Ab Rahman. 2009. Technology task Pelajar Kolej Komuniti Luar Bandar. http://eprints.uthm.edu.my/314/1/azmanirah. ICTLHE.pdf 
Sweet, R. and A. Meates. 2004. ICT and low achievers: What does PISA tell us?, In Promoting equity through ICT in education: Projects, problems, prospects, ed. A. Karpati. 2004. Budapest: Hungarian Ministry of Education and OECD. http://www.oecd.org/edu/preschoolandschool/ programmeforinternationalstudentassessmentpisa/33680762.pdf (accessed 20 November 2012).

Teck, S. H. and Y. L. Lai. 2011. An empirical analysis of Malaysian pre-university students' ICT competency gender differences. International Journal of Network and Mobile Technologies 2(1): 15-29.

Tengku Faekah Tengku Ariffin. 2005. Gender differences in computer attitudes and skills. Jurnal Pendidikan (UKM) 30: 75-91.

UNESCO. 2004. ICT in schools: A handbook for teachers or how ICT can create new, open learning environments, eds. J. Anderson and E. Khvilon. UNESCO, Paris.

World Health Organisation. 2012. Health topics. http://www.who.int/topics/health services_indigenous/en/(accessed 30 October 2012).

Zare-ee, A. and A. Shekarey. 2010. Comparative study of the use of ICT in English teachinglearning processes. Turkish Online Journal of Distance Education-TOJDE 11(2): 13-22.http://tojde.anadolu.edu.tr/tojde38/pdf/notes_for_editor_2.pdf(accessed 3 November 2012). 